\title{
Rynek filmowy jako część systemu masowych rynków medialnych
}

\author{
ARKADIUSZ LEWICKI
}

Film najczęściej jest postrzegany jako twór powiązany z innymi dziedzinami sztuki: literaturą, malarstwem, muzyką. Wydaje się jednak, że warto na dzieła audiowizualne spojrzeć także z innej perspektywy. Utwór kinematograficzny, by powstać, potrzebuje nie tylko talentu osób zaangażowanych w realizację, ale również odpowiednich środków technicznych oraz (a czasami przede wszystkim) nakładów finansowych i istnienia całej infrastruktury, która pozwoli nie tylko go stworzyć, ale i dystrybuować w odpowiednim obiegu. Wydaje się więc, że na utwór filmowy możemy spojrzeć także nieco inaczej, wpisującej go w cały - coraz bardziej złożony - paradygmat systemowy powiązany z innymi rynkami medialnymi.

\section{Tradycyjne ujęcie systemów medialnych}

W naukach społecznych za pierwszego badacza, który stworzył podstawy współczesnej ogólnej teorii systemów, przyjęło się uważać Ludwiga von Bertalanffy'ego ${ }^{1}$. Zdefiniował on system jako określona całość składająca się z części pozostajacych $w$ stanie interakcji ${ }^{2}$. Myśl niemieckiego biologa rozwinął amerykański matematyk Anatol Rapoport, który stwierdził, że poprawne określenie pojęcia systemu wymaga wydzielenia ze wszystkich klas, agregatów lub zjawisk tylko takich, które odpowiadaja nastęującym kryteriom:

1. system składa się z dajacych się zidentyfikować elementów,

2. pomiędzy różnymi elementami istnieje przynajmniej jedna dająca się zidentyfikować zależność,

3. niektóre zależności implikuja inne.

Trzy wymienione kryteria wystarczaja, by uznać system za statyczny. By uznać go za dynamiczny, potrzeba jeszcze takiej właściwości, by:

4. pewien kompleks zależności $w$ danym czasie implikowat pewien kompleks (albo jeden z możliwych różnych kompleksów) w czasie przyszłym ${ }^{3}$.

Co warte podkreślenia, definicje związane z systemami stosowano przede wszystkim w analizach systemów politycznych, działaniach zbiorowości i instytucji. Ma to daleko idące implikacje, artykułujące się w sposobach (przede wszystkim, choć nie wyłącznie, na gruncie polskiej refleksji medioznawczej) tworzenia definicji systemu medialnego lub (jak to jest nazywane w niektórych ujęciach) sys- 
temu komunikowania masowego. Jeśli spojrzymy choćby na schematy związane z systemowym ujęciem mediów masowych, na przykład te przedstawione przez Bogusławę Dobek-Ostrowską w książce Media masowe $i$ aktorzy polityczni $w$ świetle studiów nad komunikowaniem politycznym ${ }^{4}$ czy Macieja Mrozowskiego w publikacji Media masowe. Władza, rozrywka, biznes ${ }^{5}$, to dostrzeżemy bez trudu, że są one skoncentrowane przede wszystkim na polityczno-społecznym funkcjonowaniu mediów. U Dobek-Ostrowskiej pojawia się dodatkowo element nazwany jądrem systemu (systemem medialnym), w którym zostały umieszczone takie struktury, jak system telewizyjny, system prasowy, system radiowy, nowe media i telematyka. W polskim obiegu medioznawczym niezwykle nośna jest również teoria Daniela C. Hallina i Paolo Manciniego, którzy w książce Systemy medialne. Trzy modele mediów i polityki w ujęciu porównawczym za główne kryteria badań przyjęli cztery wyznaczniki:

1. rozwój rynków medialnych ze szczególnym naciskiem na rozwój prasy masowej,

2. paralelizm polityczny, odzwierciedlajacy stopień powiązań pomiędzy mediami i partiami politycznymi,

3. rozwój profesjonalizmu dziennikarskiego,

4. stopień i charakter interwencji państwa $w$ system medialny ${ }^{6}$.

Dzięki tym kryteriom badaczom udało się wyodrębnić trzy modele systemów medialnych, występujące w badanych przez nich krajach. Są to modele:

1. śródziemnomorski lub spolaryzowanego pluralizmu,

2. północno- i środkowoeuropejski lub demokratycznego korporacjonizmu,

3. północnoatlantycki lub liberalny.

Bogusław Nierenberg w książce Zarządzanie mediami. Ujęcie systemowe słusznie zauważa, że tę klasyfikację można by uzupełnić o model, który proponuje nazwać totalitarnym czy autorytarnym, występujący w państwach takich jak Korea Północna czy Kuba ${ }^{7}$.

Przyjęcie powyższych kryteriów oraz wywiedziony z nich podział jest oczywiście funkcjonalny - pozwala za pomocą zobiektywizowanych i w miarę porównywalnych założeń sprawdzić sposoby funkcjonowania mediów w poszczególnych państwach. Dlatego też jest niezwykle często wykorzystywany w opracowaniach poświęconych systemom medialnym poszczególnych krajów. Takie książki jak: Wybrane zagraniczne systemy medialne pod redakcją naukową Janusza W. Adamowskiego ${ }^{8}$, Systemy medialne państw Unii Europejskiej. Kraje pierwszej piętnastki pod redakcją Aleksandry Matyjaszkiewicz-Włodarskiej i Moniki Ślufińskiej ${ }^{9}$ czy Rynki medialne wybranych państw Europy Zachodniej pod redakcją Katarzyny Konarskiej ${ }^{10}$, poświęcone syntetycznym ujęciom i opisom systemów medialnych różnych państw, czy pozycje w sposób bardziej szczegółowy omawiające media poszczególnych krajów autorstwa Janusza Adamowicza ${ }^{11}$, Bartłomieja Golki ${ }^{12}$, Katarzyny Konarskiej ${ }^{13}$ czy Jolanty Dzierżyńskiej-Mielczarek ${ }^{14}$ w mniej lub bardziej wyraźny sposób odwołują się do koncepcji Hallina i Manciniego. W każdej z nich można także zauważyć koncentrację na wybranym segmencie komunikacji masowej, który za Golką można by nazwać mediami informacyjnymi ${ }^{15}$ (choć jest to - do czego odniosę się w dalszej części tekstu - zagadnienie znacznie bardziej skomplikowane). Najwyraźniej widoczne jest to w książce pod tytułem Rynki medialne wybranych państw Europy Zachodniej, która - jak się wydaje - 
została napisana według określonej struktury, powtarzanej w poszczególnych rozdziałach, poświęconych rynkom medialnym w Hiszpanii, Francji, Niemczech, Norwegii, Szwajcarii, Wielkiej Brytanii i we Włoszech. Prawie każdy rozdział składa się krótkiego wprowadzenia, opisu podstaw prawnych funkcjonowania poszczególnych rynków narodowych, a potem charakterystyki rynku prasy, rynku radiowo-telewizyjnego oraz najczęściej krótkiego podrozdziału poświęconego Internetowi i sposobom jego używania w poszczególnych krajach. W podsumowaniu część autorów wprost odwołuje się do schematu Hallina i Manciniego, próbując dopasować opisywany przez siebie rynek do któregoś z modeli przedstawionych przez włoskich badaczy. Podobną strukturę mają inne książki poświęcone systemom medialnym. W nich również autorzy analizują prawne i polityczne warunki funkcjonowania przede wszystkim prasy oraz radia i telewizji, w nowszych publikacjach refleksja jest rozszerzona o portale internetowe, najczęściej te o charakterze informacyjno-dziennikarskim. Nie chcę w żaden sposób podważać zasadności czy celowości tego typu badań, są one niewątpliwie wartościowe, przynoszą wiele interesujących obserwacji, pozwalają wskazać różnice i podobieństwa występujące między poszczególnymi państwami i rynkami medialnymi. Tyle tylko, że wychodząc od socjologiczno-politologicznych metodologii badań pomijają one znaczną część rynku medialnego czy systemu komunikacji masowej, który nie jest (przynajmniej nie w sposób aż tak bezpośredni) związany z szeroko rozumianą polityką.

\section{Czy media masowe są informacyjne?}

Redukowanie pojęcia mediów masowych jedynie do problemów rozwoju prasy masowej, zależności między mediami a systemem politycznym czy profesjonalizacji dziennikarstwa, czyli do tego segmentu mediów, który jest skupiony na informacji, wydaje się redukowaniem podwójnym. Skutkuje bowiem nie tylko zlekceważeniem innych mediów, ale także zignorowaniem faktu, że same komunikaty dziennikarskie, związane z informowaniem społeczeństwa o sprawach polityczno-społecznych, stanowią zaledwie wąski wycinek systemów prasowych, telewizyjnych, radiowych czy Internetu. Przecież nawet w dziennikach informacje polityczne stanowią jedynie część zawartości tych gazet, które są wypełnione również wiadomościami z dziedzin niemających zbyt wiele wspólnego z (na przykład) zagadnieniem wolności słowa. Prognoza pogody, wyniki ligi siatkarskiej czy piłkarskiej, plotki z życia gwiazd i gwiazdeczek oczywiście w jakiś sposób mogą być powiązane z ideologiczną linią jakiegoś konkretnego tytułu prasowego, ale jest to zależność często niezbyt istotna. Skupienie się w analizie, choćby w przypadku telewizji „ramówkowej”, na (nie)zależności programów informacyjnych, która zdaje się dominować (szczególnie w polskich) badaniach zawartości, jest oczywiście ważne i często przynosi istotne wnioski, ale nie należy zapominać, że programy informacyjne (i publicystyczne) stanowią - choć zapewne zależy to od profilu poszczególnych stacji - nie więcej niż 20 proc. całego czasu antenowego. Kanały wyspecjalizowane $\mathrm{w}$ całodobowym podawaniu informacji zbierają zaś widownię niemal nigdy nieprzekraczającą 10 proc. ${ }^{16}$ Podobnie rzecz ma się, gdy badamy rynek radiowy - oprócz kilku kanałów stricte informacyjnych cała reszta najpopularniejszych radiostacji w znakomitej większości jest wypełniona muzyką, dziś 
najczęściej wybieraną przez wyspecjalizowane algorytmy dopasowujące ją do upodobań słuchaczy, do których nadawca chce dotrzeć.

Oczywiście wiadomo, że informacje sportowe mogą być narzędziem propagandy - w czasach PRL-u nie wypadało zbyt entuzjastycznie przedstawiać zwycięstw polskiej reprezentacji piłkarskiej czy bokserskiej nad drużyną Związku Radzieckiego, dobór piosenek czy filmów często jest uzależniony od różnego typu zależności politycznych, a recenzja Kleru (2018) Wojciecha Smarzowskiego będzie miała zupełnie inny charakter w „Polityce” niż „Niedzieli”, ale nie zmienia to faktu, że media informacyjne oraz informacje w mediach stanowią jedynie część (i to procentowo niewielką) całego systemu komunikacji masowej. Wydaje się, że skupienie się na tej części rynku medialnego w badaniach medioznawczych w sporej części wynika (przynajmniej w polskiej historii rozwoju tej nauki) z ich prasoznawczo-politologicznych korzeni i faktu, iż refleksję nad mediami (przynajmniej w pierwszym okresie rozwoju tej dziedziny badań) podejmowali przede wszystkim językoznawcy i politolodzy.

\section{Holistyczny system rynków mediów masowych}

Dziś stwierdzenie, że nowe media nie likwidują mediów starszych, a stanowią jedynie ich uzupełnienie, wdaje się medioznawczym dogmatem, nad którym nie warto już dyskutować. Dlatego i dziś należy być może pamiętać o mediach, które dominowały w różnych okresach. W jednym z najbardziej klasycznych i podręcznikowych opracowań, jakim są Teorie komunikowania masowego, Denis McQuail opisując narodziny mediów masowych, przedstawia je w rozdziałach zawierających refleksje nad poszczególnymi etapami rozwoju narzędzi komunikowania na skalę masową. Są to rozdziały dotyczące rozwoju mediów drukowanych (książki i biblioteki), a potem gazet i innych mediów drukowanych, takich jak: sztuki teatralne, piosenki, traktaty, powieści w odcinkach, wiersze, pamflety, komiksy, raporty, prospekty, mapy, plakaty, muzyka, ulotki, gazetki ścienne $i$ wiele innych ${ }^{17}$. Dalej następuje opis filmu jako medium masowego, radia i telewizji, muzyki fonograficznej, a zakończeniem są rozważania o „nowych mediach” (takich jak Internet), które w momencie pisania tej książki przez McQuaila były jeszcze w pierwszej fazie swojego rozwoju. Bardzo podobne rozważania znajdziemy w książce Lyn Gorman i Davida McLeena Media i społeczeństwo. Wprowadzenie historyczne, w której autorzy rozpoczynają od refleksji nad prasą jako medium masowym, by następnie opisać powstanie przemysłu filmowego, rozwój radia i reklamy, a później (w odniesieniu do okresu powojennego) telewizji i społeczeństwa konsumpcyjnego ${ }^{18}$. Tyle tylko, że w opisie kolejnych dekad zarówno u McQuaila, jak i u Gorman i McLeana starsze media - jak na przykład film - znikają z pola widzenia i przesuwają się w rejony mediów nieistotnych, marginalnych czy po prostu niezauważanych, choć przecież wciąż odgrywają niepoślednią rolę w pejzażu medialnym. Wydaje się jednocześnie, że w wymienionych powyżej „katalogach” środków masowego przekazu brakuje kilku elementów.

Jeśli chcemy otrzymać pełniejszy (choć jednocześnie dużo bardziej skomplikowany) obraz mediów masowych, musimy dziś w obręb refleksji włączyć również inne obszary komunikowania, które można by określić mianem „mediów kreacyjno-rozrywkowych" i dołożyć do niej inne niż logocentryczne metodologie 
badań, przede wszystkim te związane z szeroko pojętymi studiami nad wizualnością. W erze cyfryzacji, oligopolizacji i konwergencji mediów wydaje się, że pojęcie ,system medialny” powinno zostać zestawione i uzupełnione o pewne treści kryjące się pod pojęciem „system branż kulturalnych i kreatywnych”. Dzieje się tak przynajmniej z kilku powodów. Mamy dziś na przykład coraz większy problem ze zdefiniowaniem samych mediów czy mediów masowych, zacierają się tradycyjne rozróżnienia i trudno dziś jednoznacznie wyznaczyć granice między poszczególnymi mediami - szczególnie analogowymi i cyfrowymi. Stajemy więc przed trudnymi problemami terminologicznymi. Możemy współcześnie na przykład pytać, czy książkę wydaną tylko w formie elektronicznej i czytaną na czytniku nadal powinniśmy nazywać książką? Czy serial zrealizowany przez Netfliksa możemy wciąż nazywać serialem telewizyjnym? Czy gazeta, która ma jedynie wydanie internetowe, nadal mieści się w obszarze badań prasoznawczych?

Jednocześnie postępująca mediatyzacja rzeczywistości sprawia, że odróżnienie realności od spektaklu medialnego staje się niezwykle trudne, o ile w ogóle możliwe. Jeśli nawet zjedzenie śniadania czy zakup nowej bluzki może być wydarzeniem medialnym w mediach społecznościowych, to zatarcie granicy między życiem a mediami nigdy nie było tak widoczne, jak to ma miejsce dziś. Do tego możemy dodać postępującą „entertainmentyzację” mediów tradycyjnych, powodującą, że muszą one - by zachować atrakcyjność i siłę przyciągania audytorium - być również kreatywne i spektakularne (w dosłownym i przenośnym znaczeniu tego słowa), co sprawia, że coraz wyraźniej przesuwają się z dziedziny mediów informacyjnych w stronę branż kreatywnych.

Jeżeli nawet zdecydujemy się na węższe spojrzenie, według którego media stanowią zapośredniczenie techniczne pomiędzy nadawcą i odbiorcą, to niewątpliwie obok mediów opisywanych w tradycyjnych książkach medioznawczych, czyli prasy, radia, telewizji i Internetu (przy założeniu, że Internet w całej swej złożoności faktycznie jest medium), powinniśmy uwzględnić takie środki zapośredniczające, jak książka, fotografia, fonografia, film, gry komputerowe, rozrywka elektroniczna. Gdybyśmy zaś chcieli rozszerzyć to pole badawcze, moglibyśmy odwołać się do definicji branż kulturalnych i kreatywnych stworzonej na przykład przez Komisję Europejską, która w roku 2012 zaproponowała, by nazywać je tak: branże bazujace na wartościach kulturowych, różnorodności kulturowej, kreatywności indywidualnej lub zbiorowej oraz umiejętnościach i talentach, mogace generować innowacje, dochody $i$ miejsca pracy poprzez tworzenie wartości społecznej i gospodarczej, w szczególności pochodzącej z własności intelektualnej; należa do nich następujace segmenty bazujace na wktadzie o charakterze kulturowym i kreatywnym: architektura, archiwa i biblioteki, rękodzieło artystyczne, sektor audiowizualny (obejmujacy film, telewizje, oprogramowanie i gry wideo oraz multimedia i nagrania muzyczne), dziedzictwo kulturowe, wzornictwo, oparte na kreatywności branże luksusowe i moda, festiwale, muzyka na żywo, przedstawienia artystyczne, literatura i działalność wydawnicza (gazety i czasopisma), radio oraz sztuki wizualne, a także reklama $^{19}$. Jak wskazuje Jolanta Dzierżyńska-Mielczarek, w Polsce terminologiczny bałagan jest jeszcze bardziej pogłębiony, ponieważ $w$ zależności od przyjętych założeń do przemystów kultury bąź sektora kreatywnego kwalifikowane były branże spośród m.in.: działalności wydawniczej, reprodukcji nośników informacji, produkcji zabawek, handlu detalicznego (antykami), sprzedaży gazet, książek, muzyki, na- 
grań video, ustug telewizji kablowej, wydawania oprogramowania, specjalistycznego programowania oraz ustug designerskich, ustug fotograficznych, reklamy, działalności związanej z organizacja targów, wystaw, kongresów, tworzenia, dystrybucji, wyświetlania filmów, nagrań video i programów telewizyjnych, nagrań dźwiękowych i muzycznych, nadawania programów, twórczości literackiej, artystycznej, działalności instytucji sztuki, agencji informacyjnych, muzeów i obiektów zabytkowych ${ }^{20}$.

By nieco uprościć ten niezwykle obszerny i skomplikowany system zależności, chciałbym zaproponować nieco bardziej ograniczoną, a jednocześnie zdecydowanie bardziej holistyczną niż ujęcia tradycyjne koncepcję systemu współczesnych masowych rynków medialnych. Termin „system masowych rynków medialnych” pozwala $z$ jednej strony na spojrzenie znacznie szersze i wskazuje na pomijane często w dotychczasowych rozważaniach elementy, a z drugiej strony - co zostanie wyjaśnione w dalszej części tekstu - jest również propozycją zakorzenioną mocno w ekonomicznej realności czasów współczesnych, nie jest więc jedynie postulatem teoretycznym, ale empirycznie zakotwiczoną w badaniach nad dzisiejszymi zależnościami biznesowymi występującymi na rynku mediów masowych. W tak rozumianym systemie masowych rynków medialnych mieściłyby się więc:

1. media z istotnym komponentem informacyjnym, czyli:

rynek prasy,

rynek telewizyjny,

rynek radiofoniczny,

rynek internetowy;

2. media $\mathrm{z}$ istotnym komponentem kreacyjno-rozrywkowym, czyli:

rynek wydawniczy,

rynek filmowy,

rynek fonograficzny,

rynek wystawienniczy,

rynek sztuk performatywnych i eventowy,

rynek cyfrowej rozrywki interaktywnej,

rynek reklamowy.

Zaproponowany podział ma oczywiście charakter uproszczony i nie uwzględnia interakcji, które występują pomiędzy różnymi rynkami, nie ulega bowiem wątpliwości, że są one dziś powiązane siecią wzajemnych interakcji. Dodatkowym problemem jest zapewne określenie ,istotny komponent” - „,informacyjny” lub „kreacyjno-rozrywkowy”, który oznacza jedynie, że w dotychczasowej refleksji nad pewnymi mediami pojawiał się wyrazisty namysł nad ich funkcją faktograficzną czy dziennikarską, w rozważaniach nad innymi kanałami komunikacyjnymi skupiano się głównie na ich funkcjach artystycznych czy ludycznych, choć przecież dziś i te funkcje są ze sobą przemieszane na różnych poziomach. Warto też, jak się wydaje, omówić pokrótce kilka innych pojęć, które pojawiają się powyżej. O ile pierwszych siedem wymienionych rynków nie budzi chyba większych kontrowersji, o tyle trzy kolejne wymagają pewnego omówienia i uzasadnienia, bo fakt, że rynek reklamy jest dziś prawdopodobnie najważniejszym z rynków, który obejmuje swoim zasięgiem wszystkie inne jest, jak sądzę, niepodważalny. 
Pojęcie „rynek wystawienniczy” najprościej można by zdefiniować jako wszelkiego typu zorganizowane sposoby publicznego i komercyjnego prezentowania przedmiotów. Mieściłyby się w nim różnego rodzaju wystawy służące rozrywce (ale i przekazywaniu informacji): od wystaw przez muzea, parki rozrywki, galerie sztuki, aż po targi branżowe czy całą gamę reklamy zewnętrznej (outdoorowej). Historycznie początek tego przemysłu można datować na połowę XIX w., gdy w roku 1851 odbyła się w londyńskim Hyde Parku Exibition of the Works of Industry of All Nations. Jeśli uświadomimy sobie, że paryską Exposition universelle w roku 1900 odwiedziło ponad 50 mln gości ${ }^{21}$, w roku 2017 Luwr zwiedziło 8,1 mln turystów ${ }^{22}$, a od otwarcia podparyskiego Disneylandu w 1992 r. bawiło się tam ponad 300 mln wycieczkowiczów ${ }^{23}$, to okaże się, że pomijanie tego typu przekazów w refleksji nad komunikowaniem masowym nie jest zasadne. A jeśli dodamy do tego olbrzymi dziś sektor marketingowo-reklamowej komunikacji zewnętrznej w postaci plakatów, banerów, billboardów, ekranów reklamowych ozdabiających nie tylko nowojorski Times Square, ale i ulice nawet zapadłych miast i wiosek, okaże się, że jest to jeden z ważniejszych rynków mediów masowych.

Wydaje się, że w dzisiejszym pejzażu mediów o szerokim oddziaływaniu społecznym nie można również pominąć sztuk performatywnych i eventowych teatru, opery, baletu, kabaretu, musicalu, ale i koncertu muzycznego czy politycznego meetingu, które zakładają (przynajmniej prymarnie) fizyczną obecność widza i element występu na żywo. Gdyby szukać prostej definicji, to pod tym pojęciem kryłyby się wszelkie zorganizowane formy ustrukturyzowanej i komercyjnej prezentacji osób z udziałem publiczności. Dziś (choć przecież w czasach historycznych - jeśli weźmiemy pod uwagę efekt skali - było podobnie) one również są środkami komunikowania masowego. Skoro na koncercie Jeana-Michela Jarre'a w Moskwie (1997) czy Roda Stewarta na brazylijskiej Copacabanie (1994) pojawiło się ponad 3,5 miliona fanów ${ }^{24}$, to odmawianie tym wydarzeniom przynależności do komunikacji masowej również wydaje się nieuzasadnione. A jeśli uświadomimy sobie, że najpopularniejsze przedstawienie odtwarzane przy udziale publiczności, czyli Upiór w operze (The Phantom of the Opera) Andrew Lloyda Webbera, zarobiło ponad dwukrotnie więcej niż najbardziej dochodowy film wszech czasów, czyli Avatar (2009) Jamesa Camerona, to stanie się to jeszcze bardziej widoczne. Na oficjalnej stronie musicalu można przeczytać, że przyniósł on dochód w wysokości ponad sześciu miliardów dolarów, został obejrzany przez ponad 140 mln widzów, wystawiony w 166 miastach 35 krajów, w 15 różnych językach ${ }^{25}$. Dodatkowym argumentem przemawiającym za włączeniem tego typu wydarzeń w krąg systemu rynków medialnych byłby fakt, że dziś nawet występy na żywo nie obywają się bez elementów mediów zapośredniczających - fragmenty filmów są coraz częściej integralną częścią spektakli teatralnych, na koncertach widzimy (najczęściej przez ekran kamery w telefonie nagrywającej wydarzenie) wielki telebim, na którym jest prezentowana postać naszego idola itp. ${ }^{26}$

Pomijanie tego typu fenomenów w rozważaniach nad współczesnymi mediami masowymi wydaje się chyba nieuzasadnione, podobnie jak brak pogłębionej refleksji (ekonomicznej, kulturowej, medioznawczej) nad największym dziś przemysłem rozrywkowym, którym stała się produkcja i dystrybucja gier komputerowych. A przecież przychody sektora gier wyniosty w roku 2018 blisko 44 miliardy dolarów. Wedtug Entertainment Software Association liczba ta przekracza zysk osiag- 
nięty przez producentów w Hollywood, którzy pomimo rekordowo dobrego roku dla kinematografii zarobili niecate 42 miliardy ${ }^{27}$.

W powyższej analizie próbowałem nie tylko zawrzeć podział współczesnych rynków mediów masowych, ale także wskazać na fakt, że znajdujemy się dziś w sytuacji daleko idącej konwergencji tych mediów, ich wzajemnego przenikania się, tworzenia systemów granicznych, niejasnych, hybrydycznych. Warto więc zaznaczyć, że dziś rynkiem dominującym, zawierającym niemal wszystkie inne, będzie rynek reklamowy, a poza nim może się sytuować naprawdę niewielka liczba wydarzeń medialnych. Drugim rynkiem dominującym jest rynek internetowy, oddziałujący na niemal wszystkie inne i pozostający w symbiozie z wszystkimi innymi. Internetowe może być dziś wszystko: książka, muzyka, radio, telewizja, nawet nadawany w streamingu koncert rockowy czy wirtualna wizyta w nowojorskim MoMA.

Oczywiście opis szeroko rozumianego rynku medialnego nastręcza całego mnóstwa problemów natury metodologicznej, wynikających z różnych tradycji badania poszczególnych obszarów przemysłu medialnego. Jednak przejście do takiego holistycznego modelu wydaje się bardzo pożądane, pozwoliłoby bowiem ukazać różnorodność mediów, ale także wskazać, jak bliskie sobie są te poszczególne rynki - szczególnie dziś, gdy wielkie koncerny medialne (działające na skalę już to globalną, już to lokalną) i tak w portfolio swojej działalności biznesowej mają znakomitą większość obszarów wymienionych powyżej.

\section{The Walt Disney Company i Grupa Medialna Agora - przykłady wspólczesnych firm medialnych}

Jeśli przyjrzymy się na przykład strukturze jednego z gigantów globalnych, czyli The Walt Disney Company, to okaże się, że podzielona jest ona na 5 segmentów. Pierwszy z nich to Media Networks, który obejmuje zasięgiem głównie telewizję i radio. A trzeba pamiętać, że Disney Company jest dziś właścicielem nie tylko jednej z klasycznych stacji telewizyjnych, czyli ABC i jej (ośmiu) różnorodnych kanałów, ale także niezwykle popularnych kanałów sportowych ESPN, które pod koniec roku 2010 posiadaty lub miaty podpisane umowy dystrybucyjne z 46 międzynarodowymi sieciami telewizyjnymi operujacymi w ponad 200 krajach $^{28}$. Channels Worldwide miał ponad 100 kanałów w 34 językach dostępnych w 166 krajach. Poza tym Disney jest właścicielem stacji radiowej, która (podobnie zresztą jak większość wymienionych powyżej stacji telewizyjnych) ma również swoje wcielenia internetowe. Firma jest również współwłaścicielem platformy Hulu, a na rok 2019 była zapowiadana premiera jej własnej platformy streamingowej Disney+.

Kolejnym segmentem działalności kompanii jest część nazwana Park and Resorts, która zarządza parkami rozrywki rozsianymi po różnych kontynentach. Studio Entertainment to oddział nadzorujący produkcję filmową, która obecnie jest prowadzona nie tylko pod szyldem Disneya, ale również firm wchłoniętych przez giganta, takich jak: Pixar, Marvel, Touchstone czy Lucasfilm (a po zakończeniu wciąż trwającego procesu przejmowania przez Disneya wytwórni Fox znajdują się tu także filmy produkowane pod nazwą tej wytwórni). Jednak Studio Entertainment to również Disney Theatrical Productions, zajmująca się przenoszeniem na deski 
teatralne filmów Disneya, na przykład święcącego sukcesy na Broadwayu (choć wystawianego też w innych teatrach muzycznych) Króla Lwa (The Lion King). W skład tego oddziału wchodzą również wytwórnie fonograficzne (Walt Disney Records, Hollywood Records, Lyric Street Records, Buena Vista Concerts i Disney Music Publishing). Z kolei Consumer Products jest związany przede wszystkim z przemysłem wydawniczym, zwłaszcza tym skierowanym do dzieci. Disney jest jednym z największych dostarczycieli książek oraz magazynów dla najmłodszych czytelników, a po przejęciu Marvela i praw do Gwiezdnych wojen wydaje także komiksy i książki związane z tymi dwoma uniwersami.

Piąty oddział firmy nazywa się Interactive Media i, jak sama nazwa wskazuje, jest związany głównie z tworzeniem gier, aplikacji i serwisów internetowych zapewniających interaktywną rozrywkę. The Walt Disney Company działa więc w zasadzie na wszystkich wymienionych powyżej rynkach medialnych: firma ma tytuły prasowe (choć nie ma wśród nich gazet opiniotwórczych), stacje telewizyjne, radiowe oraz ważne platformy internetowe, ale również jest zaangażowana w działalność wydawniczą, filmową, fonograficzną, wystawienniczą, sztuki performatywne, rozrywkę elektroniczną, a także (choć w sposób pośredni) w rynek reklamowy.

Podobnie rzecz wygląda, gdy przyjrzymy się jednej z największych spółek medialnych w Polsce, czyli Grupie Medialnej Agora, kojarzonej głównie z „Gazetą Wyborczą",choć to przecież nie jedyny tytuł prasowy, który znajduje się w portfolio Grupy wydającej również „Logo”, „Avanti”, „Kuchnię” czy „Opiekuna”, a także mającej trzy własne drukarnie offsetowe w Warszawie, Tychach i Pile ${ }^{29}$. Ponadto Agora to wydawnictwo, w którego ofercie, jak reklamuje się ono na swojej stronie internetowej, można znaleźć dzieła wybitnych polskich reportażystów, intelektualistów i publicystów, dzieła klasyczne wielkich twórców, użyteczne i inteligentne przewodniki, publikacje popularnonaukowe, psychologiczne oraz poradniki ${ }^{30}$. Z wydawnictwem są połączone internetowe księgarnie: Kulturalny sklep i Publio. Agora zajmuje się także fonografią, wydając albumy muzyczne. Grupa jest również organizatorem takich wydarzeń, jak Nagroda Literacka „Nike”, Europejskie Targi Muzyczne Co jest Grane czy Olsztyn Green Festival. Grupa Medialna jest ponadto współwłaścicielem kilku stacji radiowych: TOK FM, Radia Złote Przeboje, Radia Pogoda i Rock Radia czy (od 2019 r.) Radia Zet oraz takich portali internetowych jak: Gazeta.pl, Sport.pl, eDziecko.pl, Ugotuj.to czy Plotek.pl, by wymienić tylko kilka najbardziej rozpoznawalnych. Do spółki należy także firma AMS specjalizująca się w reklamie outdoorowej. Agora ma też sieć kin Helios i firmę dystrybucyjną Next Film, która wprowadzała na polskie ekrany takie tytuły, jak Bogowie (2014) Łukasza Palkowskiego, Sztuka kochania. Historia Michaliny Wisłockiej (2017) Marii Sadowskiej, Pokot (2017) Agnieszki Holland czy Miszmasz, czyli Kogel Mogel 3 (2019) Kordiana Piwowarskiego. Co prawda w tym momencie firma wycofała się z rynku telewizyjnego, sprzedając w 2018 r. swoje udziały w kanale Stopklatka, a i udział w rynku rozrywki interaktywnej ograniczyła się w zasadzie do portalu Quizy.Gazeta.pl, jednak prowadzi ona dziś swoją działalność niemal we wszystkich sektorach rynku medialnego, choć oczywiście skala tej działalności w żaden sposób nie jest porównywalna z działaniami takich medialnych gigantów jak Disney czy WarnerMedia. Warto w tym miejscu zwrócić uwagę, że na przykład w ostatnim kwartale 2018 r. całkowite przychody Agory wyniosły 346,1 mln zł, z czego największe zyski przyniosły wpływy ze sprzedaży usług reklamowych 
(165,2 mln zł), a niemal jedną trzecią całkowitej kwoty stanowiły dochody ze sprzedaży biletów do kin Helios (80,2 mln zł) oraz ze sprzedaży barowej w tych kinach (31,3 mln zł), a jedynie 36,2 mln zł pochodziło ze sprzedaży wydawnictw ${ }^{31}$.

Jeśli wrócimy do przywołanej w pierwszych zdaniach tekstu definicji Ludwiga von Bertalanffy'ego, w której system jest rozumiany jako określona całość składająca się z części pozostających w stanie interakcji, to trudno nie dostrzec relacji między różnymi elementami szeroko ujmowanego systemu komunikacji masowej, między mediami z komponentem informacyjnym a mediami kreacyjno-rozrywkowymi, bowiem działalność wielkich grup medialnych sprawia, że nie sposób tych obszarów traktować dziś oddzielnie.

\section{Rynek filmowy jako część systemu masowych rynków medialnych}

Przemysł filmowy, bo na nim chciałbym się skupić w ostatniej części tego artykułu, jest - jako element systemu masowych rynków medialnych - istotny z czterech powodów: historycznego, ,genologicznego”, ekonomicznego i społecznego.

Jeśli spojrzymy na rynek filmowy pod kątem jego znaczenia historycznego, to nie ulega wątpliwości, że przemysł filmowy był drugim, po rynku prasy wysokonakładowej, wytwórcą komunikatów medialnych trafiającym do naprawdę szerokiej publiczności. Wystarczy sobie uświadomić, że w roku 1930 cotygodniowe audytorium amerykańskich kin liczyło około 90 mln widzów. Jeśli dodamy do tego fakt, że ówczesna populacja USA wynosiła $120 \mathrm{mln}$, to okaże się, że co tydzień trzy czwarte z niej uczestniczyło w seansie filmowym ${ }^{32}$, na który składał się przecież nie tylko główny film, będący podstawowym punktem programu, ale także różnego typu filmy krótkometrażowe, w sporej części dokumentalne lub reportażowe. Film nie był więc jedynie jarmarczną rozrywką, ale również jednym z nielicznych sposobów zdobycia informacji o świecie, wydarzeniach społecznych, politycznych, sposobem na poznanie odległych zakątków świata. Różnego typu aktualności, kroniki, filmy podróżnicze czy przyrodnicze były przez pierwszą połowę XX w. jedną z nielicznych form kontaktu szerokiej publiczności z wizualnymi (a po przełomie dźwiękowym - audiowizualnymi) obrazami różnych części świata. Warto więc pamiętać, że kino było nie tylko miejscem, gdzie rozwijał się przemysł kreacyjno-rozrywkowy, nie tylko był okazją do spotkania ze sztuką, ale także medium $\mathrm{z}$ istotnym komponentem informacyjnym, wszak Polską Kroniką Filmową przestano poprzedzać seanse filmowe dopiero w roku 1994. Oczywiście współcześnie obecność choćby filmów dokumentalnych w kinach jest znacznie ograniczona i stanowi jedynie niewielki ułamek rynku kinowego, ale przecież do dziś różne festiwale filmu dokumentalnego cieszą się sporą popularnością, czasami pojawiają się dzieła, które mają prawdziwą moc społecznego oddziaływania, jak na przykład Fahrenheit 9/11 (2004) Michaela Moore'a, który nie tylko został nagrodzony Złotą Palmą w Cannes, ale także zarobił na świecie ponad 220 mln dolarów ${ }^{33}$. A gdyby chcieć odwołać się do nieco odleglejszych czasów, to można zastanowić się, jak wielkie znaczenie dla przemian w Polsce miał fakt, że w roku 1981, w okresie karnawału „Solidarności”, w pierwszej dwudziestce najpopularniejszych filmów wyświetlanych w polskich kinach znalazły się aż 3 filmy dokumentalne: Robotnicy '80 (1980) Andrzeja Chodakowskiego i Andrzeja Zajączkowskiego, którzy przyciągnęli do kin 4784000 widzów - była to druga po Człowieku z żelaza (1980) An- 
drzeja Wajdy najpopularniejsza produkcja tego roku; Ojciec Święty Jan Paweł II w Polsce (1979) Mirosława Chrzanowskiego i Janusza Kędzierzawskiego (3 375000 widzów i 4. miejsce w boxoffice) oraz Pielgrzym (1979) Andrzeja Trzosa-Rastawieckiego, który z wynikiem $398000{ }^{34}$ widzów zajął 19. miejsce w rocznym zestawieniu. Oczywiście nie przeceniam roli, jaką odegrały te filmy, ale być może dzięki temu, że prezentowały treści niedostępne wówczas w obiegu prasowym czy telewizyjnym, w jakiś sposób przyczyniły się do zmiany nastrojów społecznych początków dekady lat 80 .

Ponieważ film był jednym z pierwszych mediów masowych, warto pamiętać, że to właśnie kinematografia stworzyła, w mniej lub bardziej wyrazistej formie, podwaliny pod wiele współczesnych gatunków medialnych. Zarówno gatunki informacyjne, jak i kreacyjno-rozrywkowe czerpią pełnymi garściami z dokonań X Muzy. Przecież film już u swego zarania (przynajmniej w teorii) miał być „nowym źródłem historii”: kroniki, filmy podróżnicze i przyrodnicze, różnego typu aktualności były pierwocinami nie tylko współczesnych filmów dokumentalnych (które, nawet jeśli incydentalnie obecne w obiegu kinowym, przecież wciąż są intensywnie obecne w ramówkach wielu stacji telewizyjnych), ale także reportaży telewizyjnych, a nawet programów newsowych. Gdyby przyjrzeć się sprawie uważniej, to okaże się, że na przykład przedstawienia Teatru Telewizji mają oczywistą proweniencję teatralną, ale już Film d'Art, nurt zainicjowany w roku 1908, miał często formę zapisu spektaklu teatralnego. A praprzodkiem teledysku były fonosceny reżyserowane przez Alice Guy i Arthura Gilberta dla wytwórni Gaumont w pierwszej dekadzie XX w. Do roku 1909 nakręcono ponad setkę tych trwających najczęściej około trzech minut dźwiękowych filmików, w których występowali najsłynniejsi piosenkarze i artyści kabaretowi ówczesnej Francji: Félix Mayol, Polin, Armand Ménard Dranem czy Harry Fragson ${ }^{35}$.

Oczywiście w obrębie gatunków kreacyjno-rozrywkowych ten wpływ jest jeszcze wyraźniejszy: serial telewizyjny czy internetowy to przecież nic innego, jak kontynuacja niezwykle popularnych w dwóch pierwszych dekadach XX w. seriali i serii kinowych - choć one same były zakorzenione w tradycji powieści odcinkowych. Komedia slapstickowa, w której wciąż ten sam Charlie, Buster czy Harold przeżywał coraz to nowe przygody, mogłaby zostać uznana za pierwowzór dzisiejszych sitcomów (choć gatunek ten ma także korzenie radiowe). Serie detektywistyczne czy westernowe, tak popularne w pierwszych dekadach kina, dały początek dzisiejszym serialom sensacyjnym, a serial-queen melodrama, których tylko w drugiej dekadzie XX w. powstało ponad 60 (łącznie ponad 800 epizodów) ${ }^{36}$, można uznać zarówno za pierwsze serie melodramatyczne, jak i za seriale, które przyczyniły się do emancypacji kobiet, ale również były pierwszymi objawami konwergencji mediów - spora część przygód dzielnych i walecznych bohaterek miała zarówno ekranowe, jak i gazetowe wersje. Praktykę tę zapoczątkował Thomas A. Edison, którego serial What Happened to Mary (1912) był również powieścią odcinkową drukowaną przez popularne wówczas czasopismo „The Ladies’ World”. W 1915 r. 6 na 7 najpopularniejszych dzienników w Nowym Jorku i wszystkie 4 gazety bostońskie drukowały powiązane z seriami kinematograficznymi opowieści w odcinkach ${ }^{37}$. Przemysł kinematograficzny wynalazł konwergencję, zanim stała się ona modna (i zanim w ogóle pojawiło się to pojęcie). 
Spoglądając na problem z perspektywy historyczno-ekonomicznej, można dojść do wniosku, że przemysł filmowy był jednym z najbardziej innowacyjnych przemysłów medialnych i wprowadzał niektóre rozwiązania biznesowe na długo przedtem, gdy sięgnęły po nie inne branże kreatywne. Przecież zanim kino zostało uznane za sztukę, było już gałęzią przemysłu. Gdy Charles Pathé w 1896 r. założył wraz z braćmi - Émilem, Théophilem i Jacques'em - firmę Pathé--Frères i zajął się produkcją filmów, już rok później weszła ona na paryską giełdę. A na pierwszym pokazie kinematografu braci Lumière, który odbył się 28 grudnia 1895 r., mieliśmy do czynienia z przynajmniej trzema rozwiązaniami, które do dziś zdają się podstawą funkcjonowania różnych branż kreatywnych. W filmie Karmienie dziecka (Repas de bébé, 1895) pojawia się (choć zapewne nieświadome i być może niespełniające wszelkich dzisiejszych definicji) lokowanie produktu - jedna z butelek stojących na stole ma widoczne logo winnicy należącej do braci Lumière. Widzowie pierwszego seansu kinowego (choć co do tego nie możemy mieć pewności) prawdopodobnie zobaczyli remake filmu Wyjście robotników z fabryki (La sortie des usines Lumière à Lyon 1895), bowiem Ludwik Lumière nakręcił ten film trzykrotnie w ciągu roku 1895 w marcu, czerwcu i lipcu ${ }^{38}$. A film uznawany za pierwszy, który zawierał fabułę Polewacz polany $(1985, \text { L'arroseur arrosé })^{39}$ - był najprawdopodobniej ekranizacją historyjki komiksowej ${ }^{40}$. Można wprawdzie narzekać na stan dzisiejszego kina, pełnego remake'ów, sequeli, rebootów i adaptacji z uniwersum Marvela czy DC lub utyskiwać, że romantyczne komedie wypełnia product placement, ale należy pamiętać, że kino od początku wykorzystywało niemal wszystkie tak dziś rozpowszechnione strategie marketingowe, choć oczywiście ich skala była inna.

Hollywood również znacznie wcześniej niż inne branże odkryło globalizację i to nie tylko w aspekcie opanowania światowego rynku kinematograficznego przez amerykańskie produkcje, rozpoczętego po I wojnie światowej, ale także przez zagraniczny outsourcing niektórych elementów produkcji filmowej, który rozpoczął się na przełomie lat 50. i 60 . Korzystając z przepisów pozwalających na dofinansowanie produkcji filmowych w Europie (np. brytyjski „Eady Plan”), wielkie wytwórnie amerykańskie przenosiły produkcję na Stary Kontynent, co sprawiło, że w latach 60. prawie dwie trzecie brytyjskich, ponad połowa włoskich i około trzydziestu procent francuskich filmów powstało przy mniejszym lub większym udziale amerykańskich pieniędzy. Gdy w 1962 r. Marshall McLuhan wydaje Galaktykę Gutenberga, w której pojawia się pojęcie „globalna wioska”, Hollywood stosuje już globalizację w swojej codziennej praktyce, obniżając koszty produkcji przez outsourcing. Jednocześnie te niejasne systemy finansowania powodują, że w latach 60. rozmywa się pojęcie „film amerykański” i wiele filmów, które rozpoczynają się planszą pokazującą ryczącego lwa MGM-u czy górę z logo Paramountu, jest klasyfikowanych jako filmy brytyjskie czy włoskie.

Kinematografia nie tylko była pierwowzorem dla sporej części gatunków informacyjnych czy kreacyjno-rozrywkowych, nie tylko jako pierwsza wprowadzała różnego typu rozwiązania biznesowe, przejmowane przez inne gałęzie przemysłów kreatywnych, ale wciąż stanowi ważną część przemysłu medialnego, który z kolei (w dobie społeczeństwa postindustrialnego czy społeczeństwa informacji) jest jedną z najważniejszych gałęzi gospodarki. Przemysł filmowy jest również swego rodzaju zwornikiem największych gigantów współczesnego przemysłu medialnego. W książce Global Media Giants z roku 2017 wszystkie amerykańskie firmy, które 
zostały wskazane właśnie jako medialni giganci o zasięgu ogólnoświatowym, były posiadaczami którejś z klasycznych hollywoodzkich wytwórni filmowych. Obok wymienionego już Disneya, National Amusements jest właścicielem Paramount Pictures, Warner Media - Warnera, Comcast Corporation - Universalu, zaś News Corporation było w posiadaniu 20th Century Fox Film ${ }^{41}$, który właśnie jest sprzedawany The Walt Disney Company ${ }^{42}$. W kontekście tej fuzji przytaczanie słów Ruperta Murdocha, który jeszcze kilka lat temu twierdził, że prawdziwie zintegrowana kompania medialna musi być zaangażowana w produkowanie rozrywki, a wejście w przemyst rozrywkowy jest częścia szerszej strategii - wejścia w samo serce przemystu medialnego ${ }^{43}$, może mieć dziś nieco ironiczny wydźwięk, ale wydaje się, że jest wciąż aktualne, czego dowodem są choćby kolejne próby podejmowane przez potentatów internetowych, by również stać się częścią filmowego biznesu. Na razie swoich sił w tym przemyśle próbuje zaledwie jedna firma $\mathrm{z}$ grupy określanej skrótem GAFA (Google, Amazon, Facebook, Apple). Jeff Bezos otworzył własną platformę Amazon Prime, produkującą filmy i seriale (a przecież jest także właścicielem „The Washington Post” i portalu IMDb), ale wydaje się, że jest jedynie kwestią czasu, gdy w produkcję treści audiowizualnych zaangażują się inni giganci internetowi.

Znaczenie przemysłu filmowego dla całego systemu komunikacji masowej jest więc istotne. Film ma niewątpliwie odrębną historię, specyfikę, znaczenie w systemie kultury i sztuki, ale jest także środkiem masowego przekazu, wplątanym (szczególnie dziś) w cały kompleks zależności i powiązań historycznych, społecznych i ekonomicznych, które wpływają na ostateczny kształt utworów audiowizualnych, niepowstających przecież w kulturowej i ekonomicznej próżni.

Wymienione powyżej powody decydują również o tym, że utwory audiowizualne miały (i nadal mają) wielką moc społecznego odziaływania. Służą socjalizacji, zapewniają tematy do codziennych rozmów (zapewne więcej osób komentuje kolejne filmy o Avengersach czy nowy odcinek Gry o tron /Game of Thrones, 2011-2019/) niż konwencje partii politycznych czy ich programy), tworzą nową mitologię i rytuały (społeczny wymiar chodzenia do kina, grupowe i indywidualne zwyczaje związane z binge-watching), poruszają (bezpośrednio lub nie) tematy ważne społecznie. Przemysł filmowy jest też oczywiście narzędziem soft power i amerykanizacji globalnego społeczeństwa - po obejrzeniu setek filmów lepiej znamy ulice Nowego Jorku niż Szczecina czy Pabianic. Dzieła rozrywkowe mogą oczywiście wpłynąć także na decyzje polityczne, wielu komentatorów zastanawiało się, czy Barack Obama wygrałby w 2008 r. wybory prezydenckie, gdyby nie to, że w drugim sezonie popularnego swego czasu serialu 24 godziny (24, 2001-2010) pojawia się czarnoskóry, ale niezwykle charyzmatyczny prezydent David Palmer (grany przez Dennisa Haysberta).

Postulowany przeze mnie holistyczny model systemu medialnego to próba spojrzenia na współczesne media z nieco innej perspektywy, zapewne trudnej do uchwycenia i wymagającej badań z różnych dziedzin nauki, ale - jak sądzę - niezbędnej, jeśli faktycznie chcemy spojrzeć na problem całościowo. Miejsce przemysłu filmowego w tym konwergencyjnym układzie było i jest wciąż istotne. Świadomość istnienia tych skomplikowanych powiązań pozwoli nam lepiej zrozumieć współczesne media, produkowane przez nie treści i sposoby, jakimi przekazy te mogą oddziaływać na społeczeństwo zarówno w wymiarze lokalnym, jak i globalnym. 
${ }^{1}$ L. von Bertalanffy, Ogólna teoria systemów. Podstawy, rozwój, zastosowania, tłum. E. Woydyłło-Woźniak, PWN, Warszawa 1984.

${ }^{2}$ K. Konarska, System mediów elektronicznych w Wielkiej Brytanii, Wydawnictwo Adam Marszałek, Toruń 2007, s. 12.

${ }^{3}$ A. Rapoport, Some System Approaches of Political Theory, w: Varieties of Political Theory, red. D. Easton, Prentice-Hall, Englewood Cliffs 1966, s. 129. Cyt. za: K. Konarska, dz. cyt., s. 12-13.

${ }^{4}$ B. Dobek-Ostrowska, Media masowe i aktorzy polityczni $w$ świetle studiów nad komunikowaniem politycznym, Wydawnictwo Uniwersytetu Wrocławskiego, Wrocław 2004, s. 72.

${ }^{5} \mathrm{M}$. Mrozowski, Media masowe. Władza, rozrywka, biznes, Wydawnictwo ASPRA-JR, Warszawa 2001, s. 123.

${ }^{6}$ D. C. Hallin, P. Mancini, Systemy medialne. Trzy modele mediów i polityki w ujęciu porównawczym, thum. M. Lorek, Wydawnictwo Uniwersytetu Jagiellońskiego, Kraków 2007, s. 21.

${ }^{7}$ B. Nierenberg, Zarządzanie mediami. Ujęcie systemowe, Wydawnictwo Uniwersytetu Jagiellońskiego, Kraków 2011, s. 52.

${ }^{8}$ Wybrane zagraniczne systemy medialne, red. J. W. Adamowski, Wydawnictwa Akademickie i Profesjonalne, Warszawa 2008.

${ }^{9}$ Systemy medialne państw Unii Europejskiej. Kraje pierwszej piętnastki, red. A. Matyjaszkiewicz-Włodarska, M. Ślufinska, Wydawnictwo Adam Marszałek, Torun 2016.

${ }^{10}$ Rynki medialne wybranych państw Europy Zachodniej. Regulacje, struktura, przemiany, red. K. Konarska, Universitas, Kraków 2018.

${ }^{11}$ J. Adamowski, Czwarty stan. Media masowe w pejzażu społecznym Wielkiej Brytanii, Oficyna Wydawnicza ASPRA-JR, Warszawa 2006.

${ }^{12}$ B. Golka, System medialny Stanów Zjednoczonych, WSiP, Warszawa 2004; B. Golka, System medialny Francji, Dom Wydawniczy ELIPSA, Warszawa 2001.

${ }^{13}$ K. Konarska, dz. cyt.

14 J. Dzierżyńska-Mielczarek, Rynek mediów w Polsce. Zmiany pod wplywem nowych technologii cyfrowych, Wydawnictwo ASPRA-JR, Warszawa 2018.

${ }^{15}$ B. Golka, System medialny Francji... dz. cyt., s. 7.

${ }^{16}$ Na przykład według danych z lutego 2019 r., TVN24 miał widownię o wielkości 4,19 proc., a TVP INFO: 3,2 proc. Por. M. Kurdupski, TVP1 przed Polsatem w lutym. TVN liderem w grupie komercyjnej. „M jak miłość” hitem, https://www.wirtualnemedia.pl/artykul/ogladalnosc-telewizji-luty-2019-tvp1-lideremtvp2-przed-tvn-hity (dostęp: 15.07.2019).
${ }^{17}$ D. McQuail, Teorie komunikowania masowego, tłum. M. Buchalc, A. Szulżycka, red. naukowa T. Goban-Klas, PWN, Warszawa 2007, s. 50.

${ }^{18}$ L. Gorman i D. McLeen, Media i spoleczeństwo. Wprowadzenie historyczne, thum. A. Sadza, Wydawnictwo Uniwersytetu Jagiellońskiego, Kraków 2010.

${ }^{19}$ Komunikat Komisji z dnia 26 września 2012 r. pt. Promowanie sektora kultury i sektora kreatywnego na rzecz wzrostu gospodarczego $i$ wzrostu zatrudnienia $w$ UE. COM (2012) 0537, https://eur-lex.europa.eu/legal-content/pl/TXT/?uri=CELEX:52012DC0537 (dostęp: 17.07.2019).

${ }^{20}$ J. Dzierżyńska-Mielczarek, dz. cyt., s. 133.

${ }^{21}$ J. Osterhammel, Historia XIX wieku. Przeobrażanie świata. Czas i przestrzeń, red. naukowa W. Molik, tłum. I. Drozdowska-Broering, J. Kałążny, A. Peszke, K. Śliwińska, Wydawnictwo Poznańskie, Poznań 2013, s. 36.

${ }^{22}$ W Luwrze coraz więcej turystów, https://niezalezna.pl/213553-w-luwrze-coraz-wiecejturystow (dostęp: 15.07.2019).

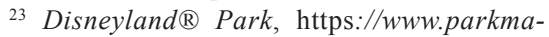
nia.pl/parki/115/o-parku/DisneylandPark.html (dostęp: 15.07.2019).

${ }^{24} 5$ największych koncertów w historii. Liczby widzów szokują, https://www.radiozet.pl/Muzyka/5-najwiekszych-koncertow-w-historii.Liczby-widzow-szokuja (dostęp: 15.07.2019).

${ }^{25}$ Facts \& Figures, https://www.thephantomoftheopera.com/facts-figures/ (dostęp: 15.07.2019).

${ }^{26}$ Zasadnym wydaje się pytanie, czy w tej samej kategorii nie mieściłyby się dziś widowiska sportowe, ale to skomplikowane zagadnienie, które wymagałoby osobnych rozważań.

${ }^{27}$ M. Szweda, Rynek gier wart więcej niż filmy z Hollywood, http://www.benchmark.pl/aktualnosci/rynek-gier-wart-wiecej-niz-filmy-zhollywood.html (dostęp: 15.07.2019).

${ }^{28}$ J. Wasko, The Walt Disney Company, w: Global Media Giants, red. B. J. Birkinbine, R. Gómez, J. Wasko, Routledge, New York - London 2017, s. 15.

${ }^{29}$ Poligrafia, https://www.agora.pl/prasa (dostęp: 15.07.2019).

${ }^{30}$ Książki, https://www.agora.pl/wydawnictwo (dostęp: 15.07.2019).

${ }^{31}$ Wyniki finansowe Grupy Agora w IV kwartale $2018 \mathrm{r}$. https://www.agora.pl/wyniki-finansowe-grupy-agora-w-4-kwartale-2018-r (dostęp: 30.07.2019).

${ }^{32}$ J. Petersen, Stulecie seksu. Historia rewolucji seksualnej 1990-1999 wedtug „Playboya”, red. H. Hefner, tłum. A. Jankowski, Wydawnictwo Rebis, Poznań 2002, s. 161. 


\section{ARKADIUSZ LEWICKI}

${ }^{33}$ Fahrenheit 9/11, https://www.boxofficemojo.com/movies/?id=fahrenheit911.htm (dostęp: 15.07.2019).

${ }^{34}$ Dane frekwencyjne podaję za: „Filmowy Serwis Prasowy. Mały Rocznik Filmowy 1981”, Warszawa 1982, s. 51.

${ }^{35}$ L. Mannoni, A. McMahan, Chronophone Gaumont, w: Encyclopedia of Early Cinema, red. R. Abel, Routledge, London - New York, 2010, s. 118.

${ }^{36} \mathrm{~B}$. Singer, Femele power in the serial-queen melodrama: The etiology of an anomaly, w: Silent Film, red. R. Abel, The Athlone Press, London 1999, s. 163.

${ }^{37}$ G. Studlar, The Perils of Pleasure? Fan Magazine Discourse as Women's Commodified Culture in 1920s, w: Silent Film, dz. cyt s. 264.

${ }^{38}$ Te daty podaje Tadeusz Lubelski w artykule Lumière i Méliès: fotografi iluzjonista inicjuja kinematograf, w: Kino nieme. Historia kina, tom I, red. T. Lubelski, I. Sowińska, R. Syska, Universitas, Kraków 2014, s. 100. Autorzy strony internetowej poświęconej twórczości braci Lumière twierdzą, że nakręcono aż pięć wersji tego filmu (z czego cztery zachowały się w archiwum), dwie pierwsze zrealizowane w marcu i maju 1895 r., dwie kolejne w marcu i sierpniu 1896 r., a ostatnią w roku 1897. https://catalogue-lumiere.com/faq-movies/ (dostęp: 12.12.2019).

${ }^{39}$ Film ten znany jest pod kilkoma tytułami: Ogrodnik i maty psotnik, Polewacz polany, Oblany ogrodnik Lubelski pisze: choć sam Louis Lumière za jedynie właściwy uważat wymyślony przez siebie tytut "Arroseur et arrosé" (czyli „Polewacz i polany”). T. Lubelski, dz. cyt., s. 95.

${ }^{40}$ Zapewne była to popularna historyjka wykorzystywana przez wielu rysowników, różne źródła przypisują jej autorstwo Hermannowi Vogelowi bądź francuskiemu rysownikowi Christophe'owi. Identyczna historyjka pojawiła się również w serii The Katzenjammer Kids jednej z pierwszych komiksowych serii, które pojawiły się w prasie amerykańskiej.

${ }^{41}$ Global Media Giants...dz. cyt., s. 9-108.

${ }^{42}$ Ostatnia z wielkich wytwórni, Columbia, należy do japońskiej korporacji Sony.

${ }^{43}$ G. Beahm, The Sun King: Rupert Murdoch in His Own Words, Hardie Grant Books, Melbourne 2012, s. 40. 